\title{
An Innovation Capability Development Process for Firms in Developing Countries: A Theoretical Conceptual Model
}

\author{
Gezahegn Tesfaye ${ }^{1}$, Daniel Kitaw ${ }^{2}$
}

\begin{abstract}
Firms in developing nations possess low innovation capabilities due to the absence of an adequate conceptual model that consolidates the innovation capability development (ICD) constructs tailored to their needs. To describe the ICD in these firms, research findings should have consolidated both the technical and financial aspects of innovation. However, they have provided only a little account of information on the ICD process via integrating the technical and financial aspects of innovation. The aim of this research is thus to develop a conceptual model of the ICD process which is highly valuable to firms in developing countries (FDC). Methodologically, this research is based on a broad literature review. Following this, two key findings were obtained. Firstly, three key constructs of ICD, namely knowledge accumulation, knowledge application and fund generation were identified. The first two constructs constitute the technical aspect and the third construct represents the financial aspect of innovation capability. Secondly, using these three key constructs, the research proposed a conceptual model that defines a process of ICD for the FDC. These findings imply that firms' ICD effort can be better explained by integrating the technical and financial aspects of innovation. As far as our knowledge is concerned, this paper is unique regarding providing a detailed review and discussion regarding the ICD process for FDC. In conclusion, the model can place a great emphasis on the understanding of the key constructs and their relationships to enhance the attitudes and practices of firms to develop their innovation capability.
\end{abstract}

Keywords: innovation capability, firms in developing countries (FDC), technical aspect, financial aspect, constructs of innovation capability

\footnotetext{
1 Gezahegn Tesfaye, Ph.D. student at Addis Ababa University, Addis Ababa Institute of Technology, School of Mechanical and Industrial Engineering, Addis Ababa, Ethiopia, e-mail: gezahegnt2000@gmail.com

2 Daniel Kitaw, Full Professor, Addis Ababa University, Addis Ababa Institute of Technology, School of Mechanical and Industrial Engineering, Addis Ababa, Ethiopia, e-mail: danielkitaw@yahoo.com
}

Received 16 January 2018; Revised 30 April 2018; Accepted 15 May 2018 
INTRODUCTION

The global competitiveness of any organization depends upon its success in creating innovation (Zawislak, Alves, Tello-Gamarra, Barbieux, \& Reichert, 2012). For firms to achieve innovation and overcome the global antagonism, they have to possess innovation capability (Lawson \& Samson, 2001; Choudhury, 2010; Silvestre \& Neto, 2014). Romijn and Albaladejo (2002) and Zawislak et al. (2012) attested that only those enterprises with strong innovation capabilities can make valuable contributions to their country's competitiveness. Many research works (such as OECD, 2005; Mojtahedzadeh \& Chettiar, 2011; Sobanke, Adegbite, Ilori, \& Egbetokun, 2013; Doroodian, Rahman, Kamarulzaman, \& Muhamad, 2014) have determined that firms of developing countries (FDC) have low innovation capabilities. The authors posited that for FDC a proper ICD process remains a major challenge.

Gamal, Salah, and Elrayyes (2011) and Kaplan (n.d.) have discussed that $R \& D$, patent, publication and citation data are the most commonly used innovation measures that can explain the innovation capability of developed country firms. Doroodian et al. (2014) and Bogers and West (2014) questioned the relevance of these measures to explain the innovation capability of FDC. This is because; innovation in FDC is challenged by many barriers that are not found in the advanced economies (Cirera \& Maloney, 2017). As Romijn and Albaladejo (2002), Auber (2005), and Cirera and Maloney (2017) indicated, innovation capability in FDC is specified by insufficient knowledge, lack of organizational facilities, absence of R\&D activities, and poor cooperation with key actors, and lack of funding for innovation. Hence, FDC must focus to a greater extent on an ICD approach.

The conceptual model by Cohen and Levinthal (1990) provided a methodology to enhance the absorptive capacity of firms through enhancing a firm's knowledge acquisition, knowledge accumulation, and knowledge application. Supported by Cohen and Levinthal (1990), Zahra and George (2002) provided a conceptual model of innovation that has added the concepts of potential and realized absorptive capacity and their dynamic interactions. Nieto and Quevedo (2005) have also discussed the key factors that affect the innovation capability of firms. Many others (e.g., Azabadi, Noorossana, Jafari, Owlia, \& Saryazdi, 2012; Bo, 2015) provided a system dynamics (SD) methodology to conceptualize the interactions between knowledge acquisition, knowledge creation, and knowledge utilization using a system dynamics approach. Moreover, Zou, Gou, and Guo (2016) provided a system dynamics model to analyze the interactions between knowledge storage, absorptive capacity, and technology innovation achievements. As a limitation, the above authors mainly focused on enhancing the technical 
aspects of innovation. On the other hand, Madsen and Smith (2008) underlined that the knowledge management aspect of innovation capability can only indicate the initial phase of ICD. Moreover, Hottenrott and Peters (2009) presented the need to generate a financial return from the sale of new products to sustain innovativeness. However, their studies emphasized the financial/commercial aspects of innovation. These show that the literature has provided only a very sparse account of information on the ICD process via integrating the technical and financial aspects of innovation. The present research highly argues the necessity to integrate the technical and financial aspects of innovation to describe an ICD process for FDC. This research is the first attempt to provide a detailed discussion to integrate these two aspects to develop an ICD process that FDC can find valuable. ICD covers a broad concept and many perspectives. The purpose of this article is not to provide a complete model of ICD. ICD can also include production and marketing aspects. The intention of this article is to mainly address the collective action of knowledge or technical and financial aspects of innovation that FDC is lacking to a greater extent, to boost innovation (Aubert, 2005; Hottenrott \& Peters, 2009; Moohammad, Aini, \& Kamal, 2014; Cirera \& Maloney, 2017). We recommended that future research workers should address production and marketing to enhance the outcome of this research.

\section{LITERATURE REVIEW}

Existing ICD literature positions the concept of ICD into different constructs (see Table 1). These include network creation, knowledge acquisition, knowledge creation, knowledge accumulation, knowledge application, absorptive capacity development, technical infrastructure development (acquisition), human capital development, marketing and commercial issues. Taking into account the broad dimensions of these constructs and also referring to the way they are reflected in the literature, this research proposes two perspectives of ICD: the technical and financial/commercial aspects. Accordingly, the technical aspect incorporates the knowledge aspects to enhance the human capital, and the organizational absorptive capacity to enhance the capability to produce innovative products. The financial/commercial aspects consist of the commercialization and financial generation of the innovative products. Nevertheless, these two aspects were not discussed as supportive aspects to each other. The present literature review examines the definitions of innovation capability and elaborates how the technical and financial aspects of innovation capability have been addressed in the existing literature. In general, the literature review provides 
an insight to create a link between the two aspects of innovation capability to address ICD for FDC (see Figure 1). The figure depicts that, to create innovation capability, both aspects are essential. Furthermore, the figure shows that the technical success of innovation should be accompanied by financial success and the resulting financial success, in turn, should enhance the innovation capability of firms. The resulting innovation capability will consecutively enhance the technical success and this cycle repeats to continuously develop the innovation capability of firms in developing nations.

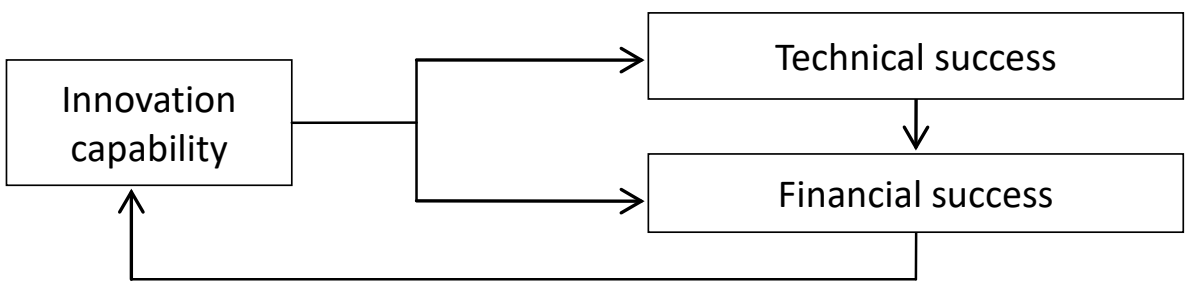

Figure 1. A conceptual approach to the literature review

Hence, the literature review first summarizes (consolidates) the views of different authors on innovation and ICD (see Table 1). Secondly, it specifically looks at the existing innovation measures and their relevance to the specificities of FDC. Thirdly, it presents the entire picture of the relevance of the existing innovation capability models to the specificities of FDC. Finally, it highlights the major gaps in the existing literature and advocates a way forward for firms in developing nations.

Narcizo, Canen, and Tammela (2017) presented different definitions of innovation capability. Particularly, Lawson and Samson (2001) defined innovation capability as the ability to continuously transform knowledge and ideas into new or significantly improved products, processes and systems for the benefit of the firm and its stakeholders. Choudhury (2010) also stated innovation capability as the ability to create new and useful knowledge based on previous knowledge. The definitions of innovation capability mainly explain the significance of knowledge acquisition and creation to enhance the knowledge base and the knowledge application capabilities of organizations. According to these definitions, innovation capability involves all the steps and efforts that firms should consider to acquire knowledge in order to develop successful products, processes or organizational systems. In the same vein, many researchers (e.g., Zahra \& George, 2002; Galanakis, 2006; Liao, Fei, \& Chen, 2007; Azabadi et al., 2012; Bo, 2015; Zou et al., 2016; Cheng, Yang, \& Sheu, 2016) have either related innovation capability to absorptive capacity 
and/or a knowledge management concept, to explain/develop the innovation capability of firms (see Table 1). However, little attention has been given to the financial aspect of innovation and its integration with the technical aspect (Madsen \& Smith, 2008; Roper, Du, \& Love, 2008; Hottenrott \& Peters, 2009; Hall \& Mairesse, n.d.).

Table 1. Main ICD constructs in academic literature

\begin{tabular}{|c|c|}
\hline Authors & Constructs addressed \\
\hline Azabadi et al. (2012) & $\begin{array}{l}\text { Knowledge acquisition, knowledge creation, knowledge } \\
\text { utilization }\end{array}$ \\
\hline Bo (2015) & Knowledge transfer, knowledge storage \\
\hline Cheng et al. (2016) & Knowledge acquisition, knowledge sharing \\
\hline Cohen and Levinthal (1990) & $\begin{array}{l}\text { Knowledge acquisition, knowledge accumulation, knowledge } \\
\text { application }\end{array}$ \\
\hline Galanakis (2006) & $\begin{array}{l}\text { Knowledge creation, new product development, product } \\
\text { success }\end{array}$ \\
\hline Gamal et al. (2011) & $\begin{array}{l}\text { Innovation process models, innovation inputs, innovation } \\
\text { outputs }\end{array}$ \\
\hline $\begin{array}{l}\text { Hanson and Birkinshaw } \\
\text { (2007) }\end{array}$ & Idea generation, idea development and idea implementation \\
\hline Liao et al. (2007) & $\begin{array}{l}\text { Knowledge sharing, absorptive capacity and innovation } \\
\text { capability }\end{array}$ \\
\hline Neely and Hii (1998) & Idea generation, selection of ideas, idea implementation \\
\hline Roper et al. (2008) & knowledge sourcing, transformation and exploitation \\
\hline $\begin{array}{l}\text { Hottenrott and Peters } \\
\text { (2009) }\end{array}$ & Sources of fund for innovation projects, rate of return to R\&D \\
\hline Hall and Mairesse (n.d.) & $\begin{array}{l}R \& D \text { investment in knowledge and networks, source of funds } \\
\text { for R\&D spending, return to } R \& D\end{array}$ \\
\hline Kaplan (n.d.) & $\begin{array}{l}\text { Innovation metrics: annual R\&D budget as a percentage of } \\
\text { annual sales, number of patents filed in the past year, number } \\
\text { of active projects, number of ideas submitted by employees, } \\
\text { percentage of sales from products introduced in the past X } \\
\text { years }\end{array}$ \\
\hline $\begin{array}{l}\text { Encaoua, Guellec, and } \\
\text { Martinez (2006) }\end{array}$ & $\begin{array}{l}\text { Innovation output in the firms of advanced countries: the } \\
\text { number of patents, the number of publications and citations }\end{array}$ \\
\hline Brooks (1994) & The relationship between science and technology \\
\hline Madsen and Smith (2008) & $\begin{array}{l}\text { R\&D investment, marketing investment, awareness creation, } \\
\text { returns from innovation }\end{array}$ \\
\hline $\begin{array}{l}\text { Czarnitzki and Hottenrott } \\
\text { (2009) }\end{array}$ & $\begin{array}{l}\text { Sources of innovation fund: external (loans from banks or other } \\
\text { debt contracts) or internal sources (retained profits or new } \\
\text { equity) }\end{array}$ \\
\hline $\begin{array}{l}\text { Romijn and Albaladejo } \\
(2002)\end{array}$ & $\begin{array}{l}\text { Determinants of innovation capability in small high-tech firms: } \\
\text { education, prior work experience and R\&D effort, external } \\
\text { interactions and proximity in network relations }\end{array}$ \\
\hline
\end{tabular}




\begin{tabular}{ll}
\hline Authors & Constructs addressed \\
\hline Sobanke et al. (2013) & $\begin{array}{l}\text { Internal factors (education, relevant prior experience, training } \\
\text { efforts, use of ICT), external factors (technical/management/ } \\
\text { financial support received) technological innovation }\end{array}$ \\
Zahra and George (2002) & $\begin{array}{l}\text { Knowledge acquisition, knowledge assimilation, knowledge } \\
\text { transformation, knowledge application }\end{array}$ \\
Zou et al. (2016) & $\begin{array}{l}\text { Establishing networking, external knowledge source, } \\
\text { knowledge storage, absorptive capacity, technology innovation } \\
\text { achievements }\end{array}$ \\
\hline
\end{tabular}

\section{The existing innovation measures and their relevance to the specificities of FDC}

Some of the studies (Gamal et al., 2011; Kaplan, n.d.) explain that the innovation capability of firms can be evaluated by innovation inputs or outputs. As an input to innovation, Hall and Mairesse (n.d.) described that for firms in developed nations, the level of R\&D expenditure had repeatedly been used as the overall indicator of their innovativeness. This is because; firms in advanced countries have a strong internal R\&D capability to create/promote innovations (Bogers \& West, 2014). However, Doroodian et al. (2014) described the shortcomings of using $R \& D$ expenditure to describe the innovativeness of FDC. As the authors argued, $R \& D$ expenditure may not essentially lead to innovation, and/or innovation is also everywhere and not just in the R\&D lab. Brooks (1994) also said that innovation involves much more than R\&D. Bogers and West (2014) specifically noted that FDC has low R\&D capabilities to create innovation. Furthermore, for firms in advanced nations, the innovation output is usually specified by the number of patents, the number of publications and citations (Encaoua et al., 2006). However, particularly, patents indicate inventions rather than innovation capabilities (Droodian et al., 2014). Hence, it can be argued that focusing on R\&D expenditure, patent, publication and citation data alone, cannot address the innovation capability problems of FDC. Hence, for these firms, the focus must to a greater extent be on building an ICD approach. In effect, the approach should help them to understand the interaction among different constructs of ICD by properly reviewing the existing ICD models in the literature.

\section{The existing innovation capability model's relevance to the specificities of FDC}

Some of the existing innovation models describe innovation as a sequential process of ICD (e.g., Neely \& Hii, 1998; Galanakis, 2006; Hanson \& Birkinshaw, 2007; Liao et al., 2007). However, ICD hardly proceeds in a sequential manner. Even though these models can be useful to provide apparent steps and explanations of the innovation process, they do not provide the required 
interactions and relationships among the different factors of ICD. Many others highly associated innovation capability with the capacity to acquire, create, share and utilize knowledge (Azabadi) et al., 2012; Bo, 2015; Zou et al., 2016). As Cohen and Levinthal (1990) also indicated, a firm's innovation capabilities and competitive advantage are based on its absorptive capacity. A firm's absorptive capacity, in turn, involves the development of the capacity to assimilate existing knowledge with the application of more effort applied to learning and the subsequent retrieval. Sobanke et al. (2013) have also described the internal and external factors influencing the technological capability of firms in developing nations. However, the conceptual framework they developed, presented the complex relationship among the identified factors in a limited way. Mohammed, Sanuri, and Rahim (2014) also reviewed the research findings of many authors and listed several elements of innovation capability that can be summed up into; researching, technology acquisition, technology development capabilities through the use of R\&D, and leadership capabilities. In most of these research works, the concept of innovation capability has been associated with the capability to develop knowledge and ideas to products, processes and systems. They provided only the technical aspects of ICD. This aspect of innovation capability can only indicate the initial phase of ICD (Madsen \& Smith, 2008).

Hall and Mairesse (n.d.) discussed that firms have to increase investments in knowledge and networking to enhance their competitiveness. Madsen and Smith (2008) addressed that the technical success of innovation is not a guarantee for its financial (commercial) success. The authors stated that firms could suffer from low R\&D funds due to funding problems and/or R\&D demand shortfalls. Furthermore, Hottenrott and Peters (2009) have determined the need to successfully generate finance from the sale of new products to avoid a lack of finance and a lack of firms' innovative capability. These researchers have proposed that the commercial success of innovation can be influenced by the effects of marketing investments, awareness creation and returns from the sale of new products (Madsen \& Smith, 2008; Hottenrott \& Peters, 2009; Hall \& Mairesse, n.d.). However, their studies mainly emphasized the financial/commercial success of innovation.

As discussed above, two research agendas (categories) are apparent concerning ICD: the innovation development (i.e., the technical aspects) and financial (commercial) aspects of innovation. However, as can be examined from table 1 and the discussion presented above, studies that address the combined and supportive efforts of the technical and financial aspects of innovation for ICD, especially in the firms in developing countries context are very sparse. Only narrow attempts have been provided by a few authors. Mojtahedzadeh and Chettiar (2011) indicated the relationship 
between knowledge, innovation and the financial performance of a firm using hypothetical assumptions without providing a detailed causal relationship between them. Moreover, Roper et al. (2008) modeled an innovation value chain as a recursive process of knowledge sourcing, transformation and exploitation (marketing aspect). However, their study was not strong enough to provide the comprehensive role of absorptive capacity, knowledge accumulation and awareness creation that create and commercialize innovations. Zawislak et al. (2012) have explicitly presented a framework for innovation capability which is constituted by four key capability elements, namely technology development capability, operations capability, management capability and transaction capability. Nevertheless, their research does not give much information on how these capabilities can be developed. For instance, the roles of need recognition for innovation and network creation, the link between marketing investment and awareness creation and their effect on promoting product sales have not been emphasized in this model.

\section{Gaps in the literature as advocacy of a new innovation model for FDC}

Based on the literature review presented above, either the most commonly used innovation measures or the innovation capability models are not sufficient to develop innovation capability for the FDC. This is because; innovation in the developing countries is challenged by barriers that are not found in the advanced economies (Cirera \& Maloney, 2017). The major specificities of innovation capability in FDC are the lack of human resources, rudimentary technology and organizational facilities, the absence of research and development activities, the low level of cooperation with key actors, insufficient knowledge and skills of innovation, institutional capacity such as machines and equipments and the lack of funding for innovation (Romijn \& Albaladejo, 2002; Auber, 2005; Cirera \& Maloney, 2017). More specifically, Cirera and Maloney (2017) noted that FDC might have neither a clear idea of the technological frontier nor the abilities to approach it. Thus, FDC needs to understand the basics of the ICD process that involves a complex and dynamic interaction among the key issues identified in the above analysis. As noted by Sobanke et al. (2013), and Cirera and Maloney (2017), innovation models have to be tailored to countries' and firms' specific nature. It is thus a prevalent issue to think of a continuous and dynamic conceptual model of ICD for FDC. This research finds the gap of integrating the two aspects of ICD as a remarkable deficiency in the literature of innovation. Hence, in this research, we argue highly that FDC needs an approach of ICD. Furthermore, the coalescing of the two aspects of innovation into a single research framework can be useful for FDC to propose innovation policy options. 


\section{RESEARCH METHOD}

This research is designed into two core parts as shown in Figure 2. As a method, the literature review first identified the most commonly used definitions of innovation capability and examined the hub of the definitions. The literature review also identified the insights of different authors regarding addressing the innovation capability constructs. To undertake this, their research findings were organized and reviewed, and the innovation capability aspects (technical and financial) and the underlying constructs they identified were summarized. The literature review also portrayed the existing innovation measures and their relevance to the specificities of FDC. Furthermore, the literature review presented the existing innovation capability model's relevance to the specificities of FDC. Finally, the literature review identified the gaps in the innovation literature as an advocacy of a new ICD model for FDC.

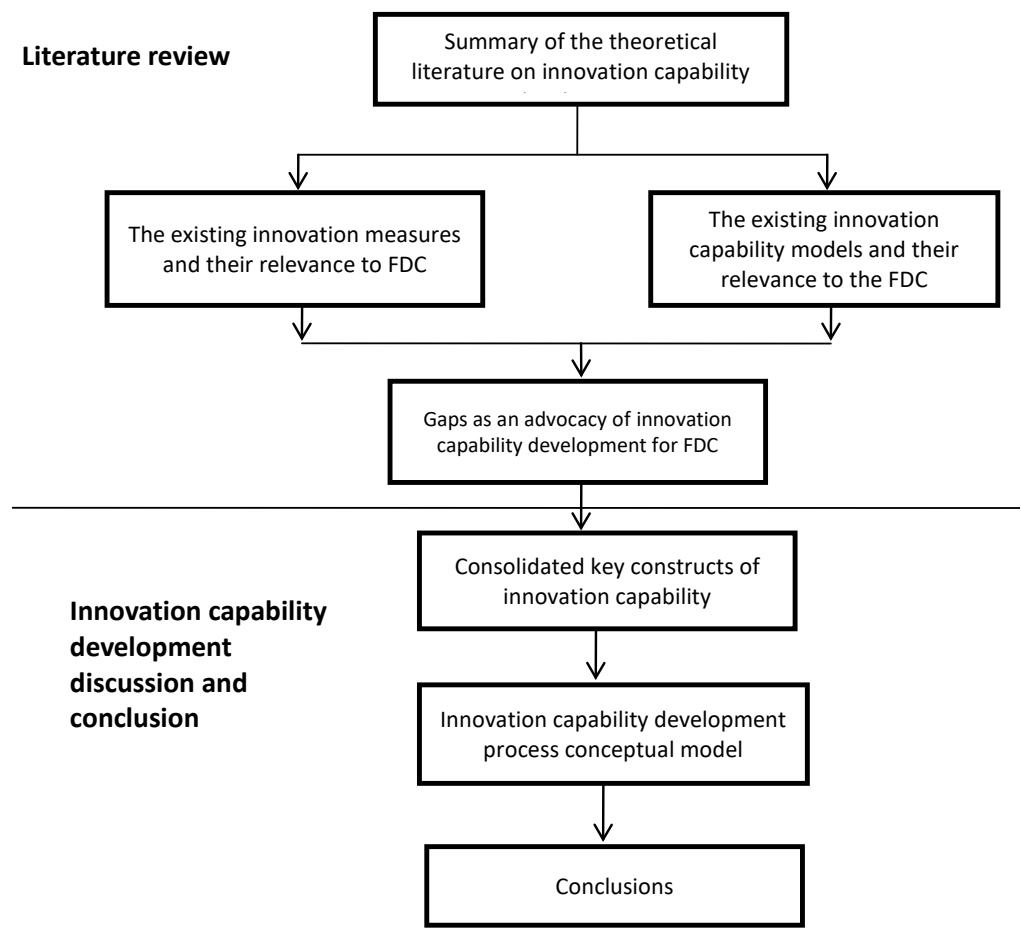

Figure 2. Research design

To review related literature, considering the aim of this research, the search phrases used were innovation capability, firm-level ICD models, and 
the nature of innovation in FDC. Long search phrases are preferred here due to their power to provide helpful approaches to address papers from a variety of existing sources. This has provided us with an opportunity to review papers over a long period. Articles for the period $1998-2018$ were considered. Using these keywords, articles in different influential and heavily cited journals in innovation, mainly from ScienceDirect, Researchgate, JSTOR, Google Scholar, and others such as world scientific, scientific information database, SAGE, Scientific electronic library online, OECD library, Blackwell publishing were considered (see Figure 3). These databases were selected based on their suitability to our actual requirements.

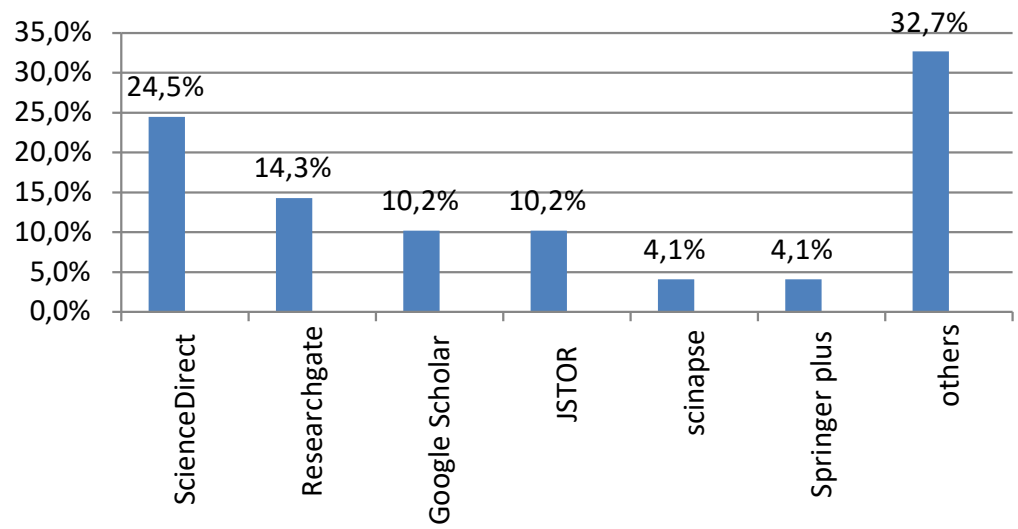

Figure 3. Databases for the selected publications

Using the search words, a total of 1009 works were found. Out of these works, 520 were rejected because of the irrelevance of their titles. The remaining 489 articles/papers were downloaded and the abstracts of all of them were scrutinized. Based on their irrelevance to the aims of this research, 440 papers were rejected. The remaining 49 papers were used to develop this paper (see Figure 4).

Two results were identified in this research. The first is the consolidated key constructs of ICD. In the existing literature, these constructs are addressed in different contexts and aspects. This research stresses the necessity to combine them into a context that FDC can easily comprehend and utilize. 


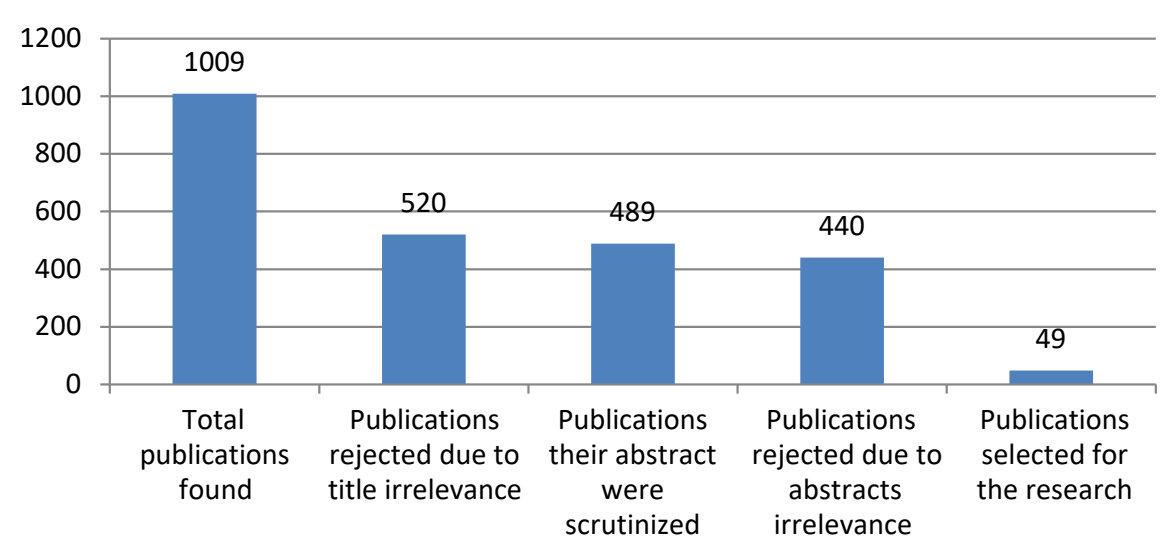

Figure 4. Articles selection process

The second result of the research is the developed conceptual model which shows a clear path of ICD. Their causal relationships have been developed to depict a scrutinized association between them. Additional key factors have also been introduced to link one construct to the other. The constructs and the added factors are connected by arrows to show a causal effect one has over the other with an arrowhead defining the direction of their causal relationships. The research finally provided conclusions on the main results of the research. Further research agendas have also been suggested.

\section{RESULTS AND DISCUSSION}

\section{Consolidating the key constructs of innovation capability}

As modeled in Figure 5, for a firm, learning knowledge from external sources should enhance the stock of knowledge of the firm. This is represented by a knowledge accumulation construct. Firms use the accumulated knowledge to generate and apply new ideas. The knowledge application activities constitute a second construct named as knowledge utilization, which in turn creates innovative outputs (such as new products). Through a dynamic process of knowledge acquisition, knowledge accumulation, and its practical application, FDC can catch up with firms in the developed world (Tesfaye \& Kitaw, 2017). In practice, this is where the technical success of innovation is apprehended.

Unless the new products are commercialized successfully in the market, innovation cannot generate income for the firms. That is, the new products must be sold to enhance financial returns for innovation. This provides the third construct identified as innovation fund generation. Financial returns will 
enhance the firm's capability to invest more in the firms' absorptive capacity to speed up the learning process for knowledge acquisition, accumulation and application. This constitutes a recurring process that will never end if the firm is to survive and succeed competitively through innovation. Following this rationale, the current study proposes that the ICD process is a continuous dynamic process that should integrate the technical and financial aspects of innovation capability (see Figure 5). The integration describes the ICD process that the FDC can find more valuable. Hence, to make this conceptualization, this research identifies three key constructs that can constitute the process of ICD for FDC. These key constructs are enclosed in rectangles in figure 5. According to this research, the first two constructs (knowledge accumulation and knowledge application) constitute the technical aspect and the third construct (innovation fund generation) indicate the financial aspect of innovation capability.

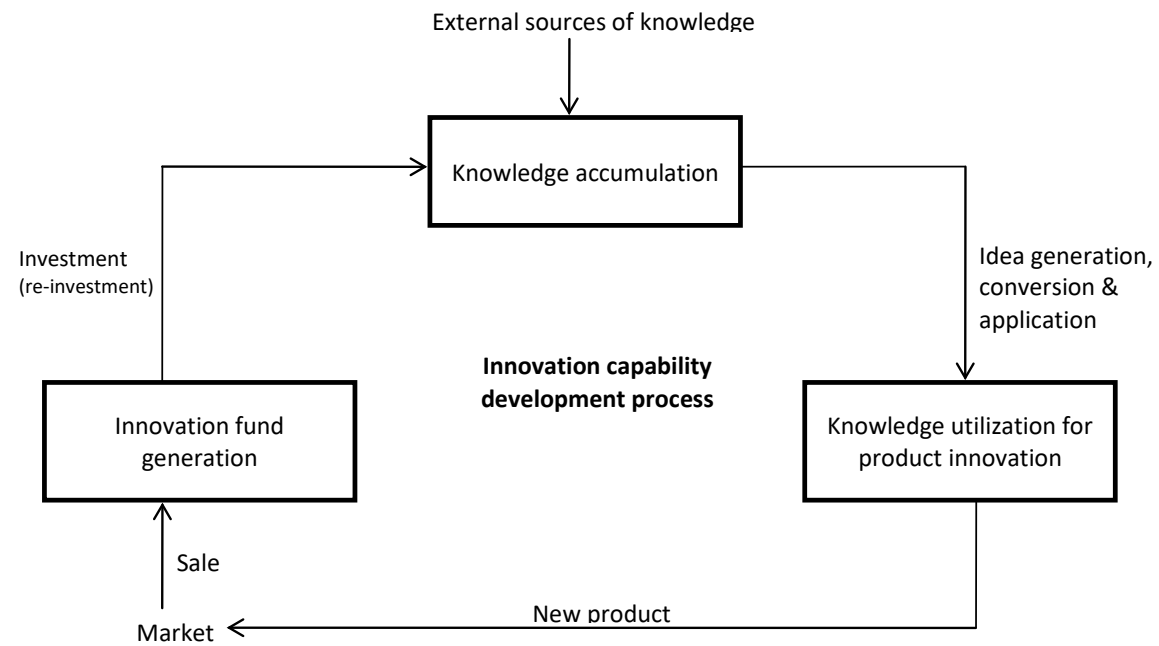

Figure 5. The three key constructs to form ICD process

\section{Building the ICD model}

The three key constructs identified, such as knowledge accumulation, knowledge utilization, and innovation fund generation, are contemplated as the building blocks of ICD for FDC. The proposed conceptual model defines the whole process of ICD. 


\section{A. Knowledge accumulation}

The FDC has to realize the importance of knowledge for learning new techniques, creating core competencies, and initiating new situations (Liao et al., 2007). Knowledge accumulation (or storage) shows the number of knowledge elements that the firms have to pile up (Zou et al., 2016). It implies continual knowledge dissemination to workforces and the organizational systems. Knowledge accumulation is needed to enhance firms' absorptive capacity to generate innovative ideas and adequate human resources with appropriate skills (Cohen \& Levinthal, 1990).

Hence, FDC has to undertake different learning processes to achieve the accumulation of organizational and technological knowledge and capabilities (Silvestre \& Neto, 2014). As Lane and Lubatkin (1998) also strongly noted, firms rely on knowledge acquired from external sources to facilitate the development of their own capabilities. This is partially influenced by firm size, age and experience (Mazzarol, Reboud, \& Volery, 2010). However, according to Ozer (2004), whatever the size of the firm, innovation development requires a continuous process that promotes the sharing of ideas and knowledge. Park (2014) has also emphasized that knowledge acquisition from external sources is crucial for the ICD of young firms. Moreover, Romijn and Albaladejo (2002), and Zahra and George (2002) emphasized that prior work experience is one of the determining factors for firms' absorptive capacity. However, Gebreeyesus and Mohnen (2013) argued that a cluster approach is the best option for small firms' innovativeness in developing countries to promote knowledge sharing and innovation. Therefore, even though the extent and content of knowledge may vary from firm to firm depending on their size, age and experience, it is inevitable for FDC to rely on external sources of knowledge. This argument is in line with the findings of Ozer (2004).

Firms with a better knowledge acquisition capability can collect more external knowledge over a given period (Cheng et al., 2016). Also, the firm's ability to acquire external knowledge is primarily determined by the nature of the external sources of knowledge and the firm's capability to network with these external sources of knowledge (Zou et al., 2016). However, prior to establishing networks with the external sources of knowledge, firms need to understand the different pressures that can force them to go for innovation. This is because most of the FDC is to a larger extent indisposed and lack the commitment to boost innovations. 


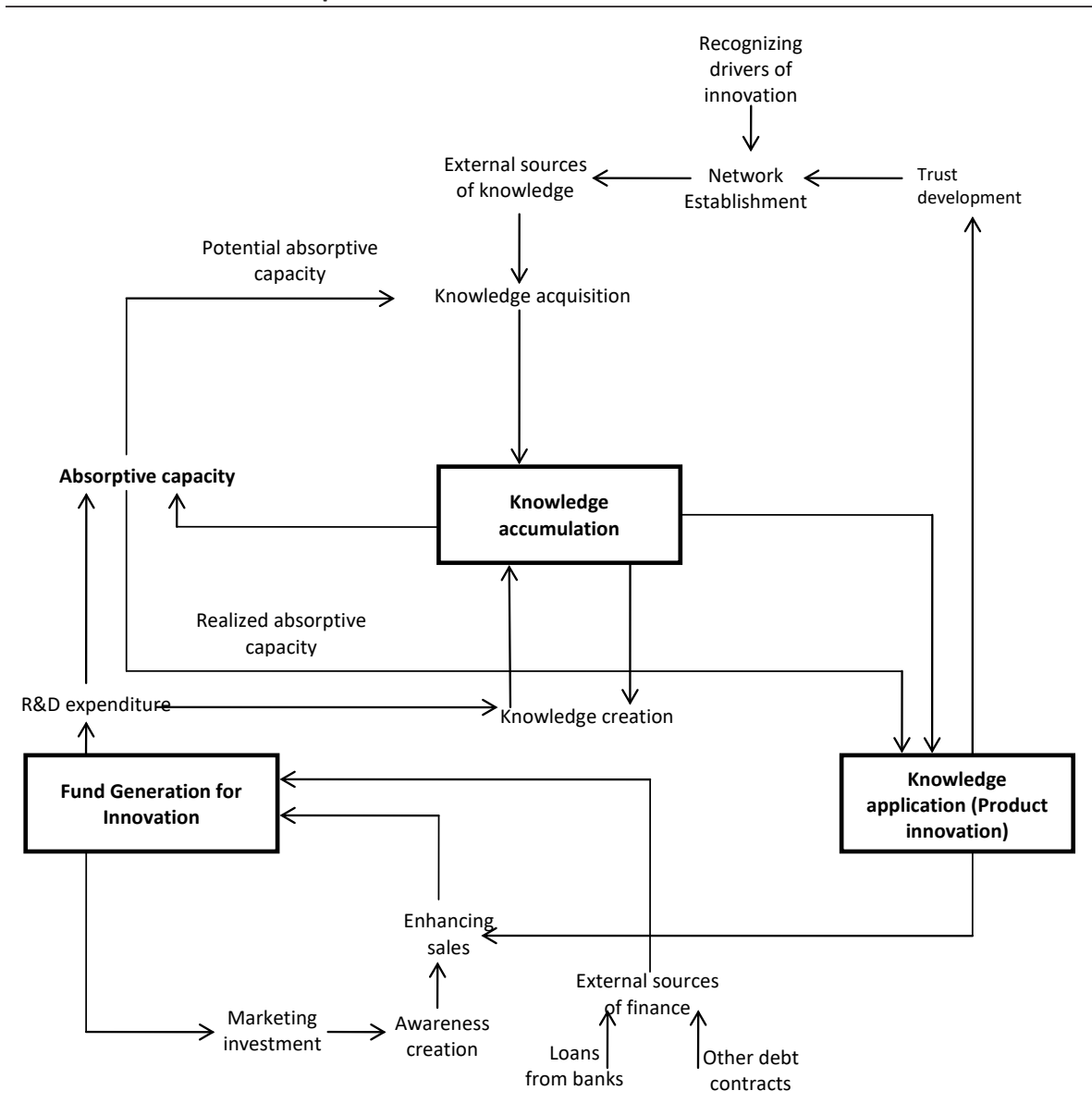

Figure 6. Proposed conceptual model for the ICD process

\section{Recognizing drivers for innovation}

Firms need to have the capacity to recognize the external pressures/drivers that force them to adopt innovation. This can enhance a firm's attitudes, willingness and commitment to initiate/stimulate innovations (Birgit, Mike, \& Chung-Shing, 2018). These authors also addressed the key drivers for innovation as the push factors of science and technology and the pull factors of customer demand. Weng, Chen, and Chen (2015) identified these drivers for innovation in detail as pressure from competitors, pressure from the government, pressure from suppliers, pressure from customers, and employee conduct that forces firms to innovate. The more the firms recognize these drivers for innovation, the more they will be influenced, 
forced, concentrated and accelerated to create networks with the external sources of knowledge to acquire knowledge.

\section{Networking with external sources of knowledge}

Once they realize the need for innovation, FDC has to identify the external sources from which knowledge, information, technologies and practices can be acquired (OECD, 2005). This is because, in developing countries, innovation is often associated with the adoption of foreign knowledge and technologies (Crossan \& Apaydin, 2010; Park, 2014; Zou et al., 2016, Tesfaye \& Kitaw, 2017). Even in firms in developed nations, 50\% of all ideas and technology come from the outside (Kaplan, website). The author justified the need for a firm to continuously and systematically network with a variety of actors intended to produce and exchange knowledge and information. Sobanke et al. (2013) determined the importance of the frequency of the contacts between the firms and the external sources of knowledge. According to the Oslo Manual (OECD, 2005), the linkages can be made to acquire/access one or more of the followings: open and free information; knowledge and technology through purchasing; capital goods (machinery, equipment, software) and services embodied with new knowledge or technology through buying. External sources with which firms can network include suppliers, competitors, partners/alliances, customers, and external experts.

\section{Absorptive capacity (potential and realized)}

Nietoa and Quevedob (2005) indicated that firms' absorptive capacity has a significant impact on their ability to innovate. Cohen and Levinthal (1990) define a firm's absorptive capacity as the ability to recognize the value of new external information, assimilate it, and apply it to commercial ends. Liao et al. (2007) posited that absorptive capacity is a function of employees' ability and motivation to acquire external knowledge and the willingness to use this knowledge in the firm's innovation capability. The knowledge and information identified and acquired from external sources have to be analyzed, processed and interpreted so that the firms can easily comprehend (understand) them. This promotes knowledge assimilation that allows firms to process and internalize externally generated knowledge (Zahra \& George, 2002). The authors also categorized absorptive capacities as a potential absorptive capacity or a realized absorptive capacity. A firm's potential absorptive capacity determines a firms' capacity to acquire and assimilate knowledge (Zahra \& George, 2002; Zou et al., 2016). These authors have also expressed that the firm's realized absorptive capacity is the firm's capacity to transform and utilize knowledge. A firm with a well-developed absorptive capacity can strengthen its knowledge base (Cheng et al., 2016). Established firms can 
further enhance their absorptive capacity based on their prior knowledge (Cohen \& Levinthal, 1990). Absorptive capabilities result from a prolonged process of investment (investments in people, science and technology and equipment) and a knowledge base within firms (Liao et al., 2007).

\section{Knowledge creation}

Firms in advanced countries focus more on in-house R\&D development to create new knowledge. On the other hand, FDC has to focus on the modifying of the imported knowledge. From a strategic viewpoint, FDC should acquire the ability to reconfigure existing competencies and create new knowledge for innovation (Cheng et al., 2016). As these authors specifically conceived, firms have to focus on the combination of the acquired new knowledge with the existing accumulated knowledge, to create the knowledge required for innovation.

\section{B. Knowledge utilization}

The stored/accumulated knowledge serves as a direct source of ideas for innovations (Brooks, 1994). The proper utilization of this accumulated knowledge to produce innovative outputs requires the capacity to retrieve and apply the knowledge (OECD, 2005). Accordingly, the firm's accumulated knowledge base enhances its technological and organizational capabilities for the innovation achievement. Technological innovation capabilities are needed to utilize technological knowledge efficiently for product and process innovations. Organizational capabilities are essential to utilize business-related and administrative knowledge, including the ability to learn and seek solutions creatively for managerial and technical problems (Silvestre \& Neto, 2014). Product innovation is achieved by introducing new or significantly improved products in technical specifications, in components and materials and in other functional characteristics. Process innovation incorporates a new or significant change in logistics, delivery or distribution methods, methods to manufacture or produce goods or services, supporting activities for processes such as maintenance systems or operations for purchasing, accounting, or computing. Managerial innovation consists of new or significant changes in organizational methods in the firm's business practices, workplace organization, and external relations. Marketing innovation integrates product design or packaging, product placement, product promotion and product pricing.

To achieve the above innovations, as noted by BPTrends (2009), there should be a good fusion between knowledge and these knowledge-centric processes. As Zou et al. (2016) posited, the relations between knowledge and technology achievement are complex and dynamic. However, to associate knowledge with technology, the concept of case management can be applied 
(Davenport, 2005; BPTrends, 2009). For this purpose, firms need to have innovation case workers. They are skilled and knowledgeable workers, whose primary job is to innovate or adjust technologies and work practices through managing a complex set of value-adding steps from its conception to its completion (BPTrends, 2009). The set of interactions among individuals and other relevant participants (such as customers and suppliers) from initiation to completion can associate knowledge with the required technology. In detail, the steps involve knowledge acquisition, assimilation, transformation and application (Zahra \& George, 2002; Zou et al., 2016). As Romijn and Albaladejo (2002) examined, firms adapt, improve and develop technologies based on the knowledge and technological capability they acquired. Accordingly to authors (such as Brooks, 1994; Zahra \& George, 2002; Aubert, 2005; BPTrends, 2009; Cirera \& Maloney, 2017), the accumulated knowledge base will then be utilized for creating procedures for processes; automating processes; improving administrative and operational processes; creating techniques and methods of design. Furthermore, it will be used to develop and commercialize products, to develop the practice of research as a source for development, to assess and assimilate new human skills and capabilities; to build the ability to assess technology in terms of its wider social and environmental impacts; and to develop more efficient strategies of applied research, to develop and refine new technologies.

\section{Fund generation for innovation}

One of the crucial determining factors for firms' innovativeness is the availability of financial capabilities. Sources of investment in innovation can be external or internal. External sources can be loans from banks or other debt contracts. Internal sources include retained profits from new products. Though internal sources are supposed to be the primary sources to finance innovation projects, as compared to debts, FDC is assumed to be inexperienced and less capable of generating such funds (Czarnitzki \& Hottenrott, 2009). Moreover, these firms do not have the required relationships with the external sources of finance. Hence, these firms should have a return generation capability: the firm's capability to generate money from its innovation expenditures. According to the OECD (2005), total expenditure on innovation is the sum of expenditures on its innovation activities such as in-house R\&D (include current expenditures including labor costs and capital expenditures on buildings and equipment specifically for R\&D); external R\&D; acquisition of machinery, equipment, software and buildings (excluding expenditure on those items that are for R\&D); acquisition of existing knowledge from other enterprises or organizations; and all other innovation activities including design, training, 
marketing, and other relevant activities. To generate these funds, firms must be able to sell a sufficient amount of its new products on the market.

Today, we are in a very competitive market, where the lifetime of most of the products is, relatively, very short. Hence, the success of launching a new product onto the market is driven by several internal and external factors. More importantly, in addition to the inherent characteristics of the new product itself, the financial return from the sale of a new product is also affected by the amount of that new products' acceptance in the market. Customers are now much more price-sensitive and quality-conscious. Particularly, in consumer goods companies, brand innovation is often more important, and this investment is usually made through marketing. Therefore, innovating products should also be accompanied by strong awarenesscreation through advertising to potential customers (Sterman, 2000). They have to launch an expensive advertising campaign to bring a new product on to the market successfully (Madsen and Smith, 2008). Investing in marketing to build brand loyalty enhances the firm's first mover advantages. Strong advertising campaigns increase sales (market demand) by telling potential customers about the improvements in the qualities of the firm's product or service. It also enhances a buyer's attitudes and perceptions of the firm's business. Some of the returns from the sale of new products should be reinvested to sustain innovation capability (Madsen \& Smith, 2008). That is, the firms need R\&D funding to invest in the workforce, investment in equipment, investment in science and technology and new knowledge creation (Hartmann, 2003). According to Maldonado (2011), R\&D investment is used to either enhance the firm's absorptive capacity via enhancing applied research capability or to enhance the firm's knowledge creation capability via enhancing their basic research capability. Both are used to enhance the stock of knowledge - including knowledge of humankind, culture and society and to devise new applications for the available knowledge. R\&D investment forms a crucial share of total innovation investments (OECD, 2005). R\&D spending also includes activities such as technical support, troubleshooting, product reformulations and quality testing.

\section{Future research area}

Based on the existing theoretical concepts, this research has developed a conceptual model of ICD. It has provided the interaction and relationships between the different constructs and factors identified in this research. For the sake of simplicity and understanding the complex interactions within ICD, we divided its whole aspect into technical and financial/commercial aspects. The marketing aspect is discussed along with the financial/commercial aspect. 
Future research work can separately consider the marketing aspect for its detailed investigation. Furthermore, in the case that innovation requires manufacturing (example new product), future research works can consider the production issue as one of the constructs into the proposed model. In addition, to prove the practical application of the proposed model, it has to be validated based on empirical data collected from representative firms. Nevertheless, this is beyond the scope of this research. To quantitatively model a process, it is necessary to include tools to develop a better insight into processes. From this viewpoint, a quantitative system dynamic methodology can be applied to analyze the complex relationship between the constructs / the factors identified. This may need further investigation to describe the detailed variables of the proposed conceptual model of the ICD process. Moreover, mathematical relationships between the process variables can be developed, simulated and sensitivity performances analyzed, to suggest appropriate policy options to enhance the innovation capability of FDC.

\section{CONCLUSION}

Firms must possess innovation capabilities to achieve innovation and to make valuable contributions to their country's competitiveness. Nevertheless, firms in developing nations lack a proper innovation capability due to the absence of a conceptual model that provides an appropriate ICD process to their requirement. The majority of the existing literature associated ICD with the capability of developing the technical aspects of innovation, which in a real sense can only describe the initial phase of innovation. This may not be indicative of its financial success. However, studies that address the combined and supportive actions of the technical and financial aspects for ICD are very sparse.

To avoid this gap, the current study develops a continuous and dynamic conceptual model of ICD. The model integrates both the technical and financial aspects of innovation to describe an ICD process to fit the needs of FDC. The model identifies three key innovation capability constructs, namely knowledge accumulation, knowledge application, and fund generation and other important factors to link and explain the constructs. The first two constructs constitute the technical aspect and the third construct indicate the financial aspect of innovation capability.

As far as the technical aspect is concerned, FDC needs to have the capacity to recognize the external pressures of innovation to enhance their commitment to stimulate innovations. The more the firms recognize them, the more they will be influenced and forced to create networks with 
external sources of knowledge. The knowledge and information identified and acquired from external sources have to be analyzed, processed and interpreted to easily internalize them. Furthermore, this knowledge has to be transformed and utilized to generate innovations. Moreover, FDC needs to have the ability to reconfigure existing competencies and create new knowledge for innovation. A firm with well-developed absorptive capacity can strengthen its knowledge base and knowledge application. Firms need to utilize technological knowledge efficiently for creating, modifying, or improving products. Product innovation is the introduction of new or significantly improved products through changes in technical specifications, in components and materials, and in other functional characteristics.

As far as the financial aspect is concerned, FDC is assumed to be inexperienced and less capable of generating funds for innovation. Firm's capability of generating financial returns from innovation will enhance their capability to re-invest in the firm's absorptive capacity, knowledge creation and marketing. Marketing investment through strong advertising campaigns is used to create strong awareness to attract potential customers. This enhances a firm's first-mover advantages and product sales, and financial returns and re-investments in innovation to sustain ICD. Finally, the proposed conceptual model can place a great emphasis on the understanding of the key constructs and the nature of their relationships to enhance the attitudes and practices of FDC to develop their innovation capability.

\section{References}

Aubert, J.E. (2005). Promoting innovation in developing countries: A conceptual framework (Working Paper No. 3554): World Bank Institute. Retrieved from http://econ.worldbank.org

Azabadi, J.H., Noorossana, R., Jafari, M., Owlia, M.S., \& Saryazdi, M.D. (2012). Knowledge management analysis: A system dynamics approach. Paper presented at International Conference on Innovation and Information Management (ICIIM 2012). Retrieved from https://www. researchgate.net/profile/Mohammad_Owlia2/publication/267784039 Knowledge Management_Analysis_A_System_Dynamics_Approach/ links/54de3b1d0cf2510fcee2528b.pdf

Birgit, P., Mike, P., \& Chung-Shing, C. (2018). Needs, drivers and barriers of innovation: The case of an alpine community model destination. Tourism Management Perspectives, 25, 53-63.

Bo, Y. (2015). Modeling of knowledge transfer in logistics supply chain based on system dynamics. International Journal of $u$ - and e-Service, Science and Technology, 8(12), 377-388. 
Bogers, M., \& West, J. (2014, June). Innovation creation and commercialization beyond the firm: A multi-level framework. Paper presented at the DRUID Society Conference. Retrieved from www.joelwest.org/Research/OI.html

BPTrends. (2009). Case management: Combining knowledge with process. Retrieved from https://www.bptrends.com/resources/glossary/case-management

Brooks, H. (1994). The relationship between science and technology. Research Policy, 23(5) 477-486.

Cheng, C.J., Yang, C., \& Sheu, C. (2016). Effects of open innovation and knowledge-based dynamic capabilities on radical innovation: An empirical study. Journal of Engineering and Technology Management, 41, 79-91.

Choudhury, J. (2010). Performance impact of intellectual capital: A study of Indian IT sector. International Journal of Business and Management, 5(9), 72-80.

Cirera, X., \& Maloney, W.F. (2017). The Innovation paradox, Developingcountry capabilities and the unrealized promise of technological catch-up. Washington, DC: International Bank for Reconstruction and Development / The World Bank.

Cohen, W. M., \& Levinthal, D.A. (1990). Absorptive capacity: A new perspective on learning and innovation. Administrative Science Quarterly, 35(1), 128-152.

Crossan, M. M., \& Apaydin, M. (2010). A multi-dimensional framework of organizational innovation: A systematic review of the literature. Journal of Management Studies, 47(6), 1154-1191.

Czarnitzki, D., \& Hottenrott. (2009). R\&D investment and financing constraints of small and medium-sized firms. Small Business Economics, 36(1), 6583. Retrieved from https://link.springer.com/article/10.1007/s11187009-9189-3

Davenport, T.H. (2005, ). Thinking for a Living. Boston, MA: Harvard Business School Press.

Doroodian, M., Rahman, M. N., Kamarulzaman, Y., \& Muhamad, N. (2014). Designing and validating a model for measuring innovation capacity construct. Advances in Decision Sciences, 2014. Retrieved from file:///C:/ Users/USER/Downloads/576596\%20(1).pdf

Encaoua, D., Guellec, D., \& Martinez, C. (2006). Patent systems for encouraging innovation: Lessons from economic analysis. Research Policy, 35(9), 1423-1440.

Galanakis, K. (2006). Innovation process: Make sense using systems thinking. Technovation, 26(11), 1222-1232.

Gamal, D., Salah, T., \& Elrayyes, N. (2011). How to measure organization innovativeness? An overview of innovation measurement frameworks and innovation audit/management tools. Egypt Innovate, Technology Innovation and Entrepreneurship Centre. Retrieved from http://www. tiec.gov.eg/backend/Reports/MeasuringOrganizationInnovativeness.pdf 
Gebreeyesus, M., \& Mohnen, P. (2013). Innovation performance and embeddedness in networks: Evidence from the Ethiopian footwear cluster. World Development, 41, 302-316

Hall, B.H., \& Mairesse, J. (n.d.). Measuring corporate $R \& D$ returns. Retrieved from http://ec.europa.eu/invest-in-research/pdf/download_en/kfg_ report_no6.pdf

Hanson, M.T., \& Birkinshaw, J. (2007). The innovation value chain. Harvard Business Review. Retrieved from https://hbr.org/2007/06/theinnovation-value-chain

Hartmann, G.C. (2003). Linking R\&D spending to revenue growth. Research Technology Management, 46(1), 39-46.

Hottenroot, H., \& Peters, B. (2012). Innovative capability and financing constraints for innovation: More money, more innovation? The Review of Economics and Statistics, 94(4), 1126-1142.

Kaplan, S. (n.d.). The complete guide to innovation metrics - how to measure innovation for business growth: Retrieved from http://www.innovationpoint.com/innovationmetrics.htm

Lane, P. J., \& Lubatkin, M. (1998). Relative absorptive capacity and interorganizational learning. Strategic Management Journal, 19, 461-477.

Lawson, B., \& Samson, D. (2001). Developing innovation capability in organizations: A dynamic capabilities approach. International Journal of Innovation Management, 5(3), 377-400.

Liao, S., Fei, W., \& Chen, C. (2007). Knowledge sharing, absorptive capacity, and innovation capability: An empirical study of Taiwan's knowledgeintensive industries. Journal of Information Science, 33 (3), 340-359.

Madsen, E.S., \& Smith, V. (2008, November). Commercialization of innovations and firm performance. Paper presented at the Southern Economic Association Conference. Retrieved from https://www.researchgate.net/ publication/46470074

Maldonado, M.U. (2011). Dynamics, structure and performance of innovation systems: A complex systems modeling approach. Retrieved from https:// pdfs.semanticscholar.org/b55f/9d15f37e0cd164fdf17aa1633dbd3387 5d99.pdf

Mazzarol, T., Reboud, S., Volery, T. (2010). The influence of size, age and growth on innovation management in small firms. Int. J. Technology Management, 52(1/2), 98-117.

Mohammed, M., Sanuri, S., \& Rahim, A. (2014). The effect of TQM practices on technological innovation capabilities: Applying on Malaysian manufacturing sector. International Journal for Quality Research, 8(2), 197-216.

Mojtahedzadeh, R., \& Chettiar, V. (2011). A structural relationship between knowledge management, innovation, and performance of Iranian industries: A theoretical approach. International Journal for Quality Research. 8(2), 231 - 235.

Moohammad, A.Y., Aini, Y.N., \& Kamal, E.M. (2014). Influences of firm size, age and sector on innovation behaviour of construction consultancy 
services organizations in developing countries. Business Management Dynamics, 4(4), 1-9.

Narcizo, R.B., Canen, A.G., \& Tammela, I. (2017). A conceptual framework to represent the theoretical domain of innovation capability in organizations. Journal of Entrepreneurship, Management and Innovation, 13(1), 147-166.

Neely, A., \& Hii, J. (1998). Innovation and business performance: A literature review. Cambridge University Press. Retrieved from http://ecsocman. hse.ru/data/696/521/1221/litreview_innov1.pdf

Nieto, M., \& Quevedo, P. (2005). Ábsorptive capacity, technological opportunity, knowledge spillovers, and innovative effort. Technovation, 25, 1141-1157.

OECD. (2005). Guidelines for collecting and interpreting innovation data. Paris: OECD Publishing.

Ozer, M. (2004). Managing the selection process for new product ideas. Research Technology Management, 47(4), 10-11.

Park, S. (2014). Analyzing the efficiency of small and medium-sized enterprises of a national technology innovation research and development program. SpringerPlus, 3(403), 1-12.

Romijn, H., \& Albaladejo, M. (2002). Determinants of innovation capability in small electronics and software firms in Southeast England. Research Policy, 31(7), 1053-1067.

Roper, S., Du, J., \& Love, H.J. (2008). Modeling the innovation value chain. Research Policy, 37(6-7), 961-977.

Silvestre, B.S., \& Neto, R.S. (2014). Capability accumulation, innovation, and technology diffusion: Lessons from a base of the pyramid cluster. Technovation, 34, 270-283.

Sobanke, V., Adegbite, S., Ilori, M., \& Egbetokun, A. (2013). Determinants of technological capability of firms in a developing country. Procedia Engineering, 69, 991-1000.

Sterman, J.D. (2000). Business dynamics: systems thinking and modeling for a complex world. Boston, MA: Irwin McGraw-Hill.

Tesfaye, G., \& Kitaw, D. (2017). A TQM and JIT integrated continuous improvement model for organizational success: An innovative framework. Journal of Optimization in Industrial Engineering, 22, 15-23.

Weng, H.H., Chen, J.S., \& Chen, P.C. (2015). Effects of green innovation on environmental and corporate performance: A stakeholder perspective. Sustainability, 7, 4997-5026.

Zahra, S.A., \& George, G. (2002). Absorptive capacity: A review, reconceptualization, and extension. Academy of Management Review, 27(2), 185-203.

Zawislak, P.A., Alves, A.C., Tello-Gamarra, J., Barbieux, D., \& Reichert, F.M. (2012). Innovation capability: From technology development to transaction capability. Journal of Technology Management and Innovation, 7(2), 14-27. 
Zou, B., Gou, F., \& Guo, J. (2016). Absorptive capacity, technological innovation, and product life cycle: A system dynamics model. SpringerPlus, 5, 2-25.

\begin{abstract}
Abstrakt
Firmy z krajów rozwijajq̨ych się majq niskie możliwości innowacyjne z powodu braku odpowiedniego modelu koncepcyjnego, który konsoliduje konstrukty rozwoju zdolności innowacyjnych (RZD) dostosowane do ich potrzeb. Dla opisu RZD w tych firmach, wyniki badań powinny skonsolidować zarówno techniczne, jak i finansowe aspekty innowacji. Jednakże zapewniajq one jedynie niewiele informacji na temat procesu RZD poprzez integrację technicznych i finansowych aspektów innowacji. Celem badania jest opracowanie konceptualnego modelu procesu RZD, który jest cenny dla firm z krajów rozwijajqcych się. Pod względem metod badania oparte sq na szerokim przeglądzie literatury, na podstawie kórego uzyskano dwa kluczowe wnioski. Po pierwsze, zidentyfikowano trzy główne konstrukty RZD, a mianowicie akumulację wiedzy, zastosowanie wiedzy i generowanie funduszy. Pierwsze dwa konstrukty stanowiq aspekt techniczny, a trzeci stanowi finansowy aspekt zdolności innowacyjnych. Po drugie, wykorzystujac te trzy kluczowe konstrukty, zaproponowano model koncepcyjny, który definiuje proces RZD dla krajów rozwijajqcych się. Ustalenia te sugerujq, że wysiłki firm w zakresie RZD można lepiej wyjaśnić, łączq̨c techniczne i finansowe aspekty innowacji. Model pozwala zrozumieć kluczowe konstrukty i ich relacje w celu wzmocnienia postaw i praktyk firm dla rozwijania ich zdolności innowacyjnych
\end{abstract}

Słowa kluczowe: zdolność innowacyjna, firmy w krajach rozwijajqcych się (FDC), aspekt techniczny, aspekt finansowy, konstrukcje zdolności innowacyjnych.

\title{
Biographical notes
}

Gezahegn Tesfaye is an academic staff member and Ph.D. student at Addis Ababa University, Addis Ababa Institute of Technology, School of Mechanical and Industrial Engineering (Addis Ababa, Ethiopia). His background is Industrial Engineering. He is currently a 4th year Ph.D. student at Addis Ababa Institute of Technology in the Industrial Engineering stream. His dissertation is in the area of ICD. Contact: gezahegnt2000@gmail.com.

Daniel Kitaw is a Full Professor of Industrial Engineering at Addis Ababa University, Addis Ababa Institute of Technology, School of Mechanical and Industrial Engineering (Addis Ababa, Ethiopia). He has comprehensive industrial consultancy and teaching experience in various organizations and academic institutions in Ethiopia. He is a founding fellow of the Ethiopian Academy of Sciences. He supervises Ph.D. students in Addis Ababa Institute of Technology. His main research interest is in the areas of quality management, innovation, and occupational safety and health. Contact: danielkitaw@yahoo.com. 